Pomimo wielu błędów i usterek, które wynikają głównie ze pobieżnej adjustacji tekstu lub zwyczajnych niedopatrzeń edytorskich, polski przekład książki ojca J.A. Jungmanna Wydawnictwa Benedyktynów Tynieckich: Liturgia pierwotnego Kościoła do czasów Grzegorza Wielkiego jest pozycją godną polecenia. Znany w świecie naukowym badacz, pionier odnowy liturgicznej oraz autor licznych i ważnych publikacji z tego zakresu gwarantuje swym nazwiskiem dobry poziom powyższego opracowania. Ponadto książka austriackiego jezuity jest łatwa w odbiorze, a zarazem bardzo interesująca w aspekcie treści. Szkoda jedynie, że na polski przekład trzeba było tak długo czekać, gdyż od daty wydania oryginału (1959) minęło już z górą pół wieku. Niemniej jednak, sama praca jest z całą pewnością przydatnym narzędziem dydaktycznym dla studentów, a także ważną lekturą uzupełniającą dla wszystkich, którzy interesują się historią liturgii chrześcijańskiej pierwszych wieków, bądź też chcą pogłębić własną religijność.

Damian Kalinowski - Lublin, KUL

\title{
Henryk PIETRAS SJ, Sobór Nicejski (325). Kontekst religijny i polityczny, do- kumenty, komentarze, Kraków 2013, Wydawnictwo WAM, ss. 236.
}

Pisanie historii - także historii Kościoła - polega na tworzeniu pewnej narracji, która upowszechniając się i zdobywając sobie coraz bardziej powszechne uznanie staje się narracją obowiązującą i kształtującą tożsamość wspólnoty, której przeszłości dotyczy. A ponieważ życie społeczności - także społeczności Kościoła opiera się w dużej mierze na narracji o przeszłości, raz utarta narracja trudna jest do zmiany, gdyż rodzi wrażenie rozmontowywania fundamentów, na których stoimy. Nic więc dziwnego, że Henryk Pietras w ostatnim zdaniu swojej książki o Soborze Nicejskim wyraża przekonanie, że nie zaszkodzi Kościołowi uświadomienie sobie, że dotychczasowa narracja o tym wydarzeniu, jest - jak to ujmuje Autor - mitem.

H. Pietras radykalnie zmienia dotychczasową narrację o Soborze Nicejskim oraz o tzw. „sporze ariańskim” (za zbędne uważam przedstawianie jej w niniejszej recenzji zakładając, że jest Czytelnikowi dobrze znana). We wstępnie do swojej książki, która podsumowuje i zbiera razem owoce jego badań, a z którymi do tej pory można się było zapoznać tylko w rozproszonych artykułach, Autor zarysowuje osobistą drogę badawcza, która doprowadziła go do powatpiewania w wielowiekową tradycję i zmusiła do przemyślenia na nowo wydarzeń z IV wieku. Książka Sobór Nicejski (325) jest przede wszystkim zaproszeniem innych badaczy do przebycia jego drogi i do ustosunkowania się do nowej, proponowanej przez niego narracji na temat soboru i związanych z nim wydarzeń.

Temat książki - Autor zajmuje się przecież jednym z najważniejszych wydarzeń w historii Kościoła powszechnego - oraz jej cel, którym jest dość, przyznać trzeba, rewolucyjna zmiana w jego postrzeganiu, czynią lekturę pasjonującą. Uroku książce dodaje także jej styl, gdyż H. Pietras nie stroni od kolokwializmów i subtelnych żartów, raczej rzadko spotykanych w tzw. „literaturze fachowej”. 
Punktem centralnym pozycji jest ledwie trzystronicowe podsumowanie, w którym H. Pietras proponuje nową narrację o Soborze Powszechnym. Jak na narrację przystało jest ona bardzo zwięzła i trudno ją jeszcze streszczać na potrzeby recenzji, ponieważ jednak trzeba to uczynić, ująłbym wnioski Autora w sposób następujący: teologiczny spór Aleksandra z Ariuszem rozlał się na cały chrześcijański Wschód z powodu mającego odbyć się w Nicei wielkiego spotkania biskupów zaplanowanego przez cesarza Konstantyna na rozpoczęcie roku jubileuszowego (vicennalia); celem soboru nie było natomiast rozstrzygnięcie kwestii ariańskiej, ale świętowanie zwycięstwa cesarza nad wrogami, manifestacja jedności i pokoju oraz wypełnienie formalności związanych z powstałą po „edykcie mediolańskim", nową sytuacją chrześcijańskiej religii w Cesarstwie Rzymskim, czyli ustalenie jednej daty świętowania Wielkanocy i jednolitego wyznania wiary dla wszystkich Kościołów.

Oczywiście Autor nie każe nam przyjmować wniosków ze swoich badań bezkrytycznie. Podsumowanie, które zostało przed chwilą streszczone, poprzedzone jest ośmioma rozdziałami będącymi szczegółową analizą źródłowych tekstów (zamieszczonych także w wersji oryginalnej, greckiej), dzięki czemu Czytelnik sam może przekonać się co do jej poprawności, a tym samym poprzeć lub skrytykować wnioski, które wyprowadza H. Pietras.

Trzy pierwsze rozdziały zawierają analizę tekstów źródłowych dotyczących sporu Ariusza z Aleksandrem. Na ich podstawie H. Pietras dowodzi, że ,jeszcze pod koniec września 324 r. cesarz uważał spór Aleksandra i Ariusza za gorszący wybryk" (s. 121). Czwarty rozdział nakreśla przyczyny zwołania soboru oraz jego przebieg. Głównym powodem zwołania soboru przez cesarza było - według H. Pietrasa - otwarcie jubileuszowego roku dwudziestolecia swego panowania. „Przy tej podniosłej okazji zamierzał ogłosić uroczyście pojednanie wszystkich zwaśnionych stron, kalendarz paschalny oraz podstawową formułę wyznania wiary chrześcijańskiej" (s. 137). Po analizie w rozdziale piątym kanonów ustalonych podczas soboru w Nicei Autor sięga do właściwie jedynych tekstów soborowych, czyli do Listu Euzebiusza z Cezarei do swojego Kościoła (rozdział szósty) oraz Wyznania wiary 318 Ojców (rozdział siódmy) wykazując, że credo przyjęte w Nicei potraktowane zostało przez wszystkie Kościoły jako martwy zapis mający służyć bardziej cesarzowi niż Kościołowi. Sobór w Nicei nie zakończył więc sporów teologicznych i o żadnym powszechnym konsensusie teologicznym nie było jeszcze mowy. Ósmy rozdział tłumaczy proces kształtowania się tradycyjnej narracji o Soborze Nicejskim jako o spektakularnym zwycięstwie ortodoksji nad herezją Ariusza, w którym główną rolę odegrał Atanazy z Aleksandrii. H. Pietras analizuje trzy teksty, które obok Listu Euzebiusza z Cezarei są jedynymi tekstami posoborowymi i na podstawie których utarła się taka, a nie inna interpretacja soboru: List Konstantyna do Kościoła w Aleksandrii, List soboru w Nicei do Egipcjan oraz List Konstantyna Wielkiego do Kościołów. Autor dochodzi do wniosku, że dwa pierwsze listy są fałszerstwami sporządzonymi po śmierci Atanazego w celu umocnienia autorytetu jego następcy, biskupa Piotra, zaś z Listu Konstantyna 
wcale nie wynika, że sobór zajmował się doktryną Ariusza i że miał go potępić jako heretyka. Dopiero po wnikliwej analizie tych tekstów źródłowych, H. Pietras przedstawia w Podsumowaniu swoje wnioski, które przedstawiono wyżej.

Na koniec recenzji warto zacytować raz jeszcze Autora, który pisze we wstępie: „Książkę tę napisałem po to, by od nowa prześledzić źródła dotyczące Soboru Nicejskiego i poddać pod osąd wnikliwszych ode mnie, bo być może umyka mi coś istotnego [...], i zastanowić się nad zrewidowaniem poglądów obecnych we wszystkich podręcznikach" (s. 10). Niewątpliwie jest to pozycja o olbrzymim znaczeniu dla wszystkich badaczy starożytności chrześcijańskiej.

ks. Przemysław M. Szewczyk - Łódź, WSD

Henryk PIETRAS SJ, Sobór Nicejski (325). Kontekst religijny i polityczny, dokumenty, komentarze, Kraków 2013, Wydawnictwo WAM, ss. 236.

Tak się złożyło, że książkę Ojca Profesora Henryka Pietrasa przeczytałem dwa razy. Pierwszy raz „na gorąco” i ,jednym tchem” zaraz po jej wydaniu, drugi raz na wiosnę tego roku - uważniej i bardziej krytycznie. Książka jest napisana znakomicie. Jak zwykle u O. Pietrasa mamy do czynienia z prawdziwym śledztwem historycznym, dotyczącym okoliczności zwołania i przebiegu Soboru Nicejskiego. Autor zamieszcza najważniejsze dokumenty dotyczące tego zagadnienia, także w oryginale, wraz z tłumaczeniami i szczegółowymi komentarzami, analizuje wszystkie dostępne źródła, stawia hipotezy które odrzuca bądź akceptuje, wyciaga wnioski, jednym słowem przeprowadza prawdziwy proces poszlakowy. Rezultatem tego procesu jest orzeczenie (Podsumowanie, s. 213-215), iż sobór został zwołany przez cesarza Konstantyna dla uczczenia dwudziestolecia jego panowania, że nie miał charakteru antyariańskiego, że słynne nicejskie wyznanie wiary było niejako narzucone Ojcom Soboru przez cesarza, który sam zasugerował wprowadzenie do credo zwrotu o współistotności itd.

Jak pisze Autor - ,znaczenie wielkiego synodu w Nicei - Soboru Powszechnego Pierwszego - jako wielkiego zrywu Kościoła w obronie bóstwa Chrystusa zdaje się zatem być mitem, jak na przykład biblijny potop czy przejście przez Morze Czerwone" (s. 215). Teza rewolucyjna, aczkolwiek sam Autor używa asekuracyjnego wyrażenia „zdaje się”, co upoważnia mnie do porównania jego pracy właśnie do procesu poszlakowego. Ale według definicji „w procesie poszlakowym łańcuch wiążących się ze sobą poszlak można uznać za zamknięty tylko wówczas, gdy każda z poszlak będąca ogniwem tego łańcucha ustalona została w sposób nie budzący wątpliwości i uniemożliwiający jakiekolwiek inne rozważania”. Czy tak jest tym przypadku? Mam wątpliwości.

Punktem wyjścia do rozważań Autora jest konstatacja, że jest niemożliwe, aby Konstantyn mógł dowiedzieć się od Hozjusza osobiście bądź listownie o rezultatach jego misji dotyczącej sporu między Ariuszem i biskupem Aleksandrem i zdążyć zaprosić na czas biskupów na synod w Ancyrze lub Nicei na czerwiec 